\title{
Effect of oxygen concentration on in-vitro development of preimplantation sheep and cattle embryos
}

\author{
J. G. E. Thompson, A. C. Simpson, P. A. Pugh, P. E. Donnelly and \\ H. R. Tervit \\ Ruakura Agricultural Centre, Private Bag, Hamilton, New Zealand
}

\begin{abstract}
Summary. Two-cell sheep embryos and 2-4-cell and 8-cell cow embryos were cultured for 5 days in stoppered test-tubes in Synthetic Oviduct Fluid supplemented with $32 \mathrm{mg}$ BSA $/ \mathrm{ml}$. The medium had been previously equilibrated with one of the following $\mathrm{O}_{2}$ concentrations (sheep: $0,2,4,6,8,10,12,17,20 \%$; cow: $0,4,8,12,17,20 \%$ ). At the end of culture embryos were examined for morphology and stained to assess numbers of nuclei. Mean ( \pm s.e.m.) nuclei/embryo was highest at $8 \% \mathrm{O}_{2}$ for sheep embryos $(23 \cdot 6 \pm 3 \cdot 1), 4 \%$ for $2-4$-cell cow embryos $(23 \cdot 2 \pm 6 \cdot 1)$ and $8 \%$ for 8 -cell cow embryos $(29.6 \pm 5 \cdot 2)$. The minimum number of nuclei/embryo occurred at $20 \% \mathrm{O}_{2}$ in each case $(10 \cdot 3 \pm 0 \cdot 9,10 \cdot 3 \pm 2 \cdot 7,14 \cdot 5 \pm 2 \cdot 4$, respectively) with similar values also recorded at $0 \% \mathrm{O}_{2}(10 \cdot 8 \pm 1 \cdot 9,16 \cdot 5 \pm 6 \cdot 0,14 \cdot 6 \pm 2 \cdot 4$, respectively). Analysis of the proportion of embryos reaching at least the morula stage demonstrated a significant quadratic component for the different oxygen concentrations for sheep $(P<0.01)$ and cow $(P<0.05)$ embryos. A number of sheep and cow embryos showed abnormalities, suggesting that the culture conditions require further refinement.

The results confirm that, under lowered oxygen levels, development of sheep and cattle embryos can occur through the 8- to 16-cell block in a simple defined medium without somatic cell support.
\end{abstract}

Keywords: sheep; cattle; embryos; oxygen; culture

\section{Introduction}

Little is known of the requirements for development of preimplantation sheep and cattle embryos in vitro. It has been established that embryos from these species often fail to develop past the 8 - to 16-cell stage in defined media under standard incubation conditions such as $37-39^{\circ} \mathrm{C}$ under $5 \%$ $\mathrm{CO}_{2}$ in air (Wright \& Bondioli, 1981). Thus the fourth cell cycle appears to be critical for development and does not proceed normally under in-vitro conditions (Gandolfi \& Moor, 1987). Successful development through this stage can be achieved when embryos are incubated in co-culture with somatic cells, in particular oviduct epithelial cells (Gandolfi \& Moor, 1987; Rexroad \& Powell, 1988; Eyestone \& First, 1989). However, it has also been reported that development of sheep, goat and cattle embryos can be achieved without somatic cell support if incubated in defined media under a gas atmosphere of $5 \% \mathrm{CO}_{2}, 5 \% \mathrm{O}_{2}, 90 \% \mathrm{~N}_{2}$ (Tervit et al., 1972; Tervit \& Rowson, 1974; Quinn et al., 1984; Walker et al., 1988). Indeed, Tervit et al. (1972) reported that oxygen concentrations of 0,5 or $10 \%$ were superior to air in terms of embryo development. However, other investigators have shown no beneficial effects of incubating sheep embryos in a reduced oxygen atmosphere (Wright et al., 1976; Betterbed \& Wright, 1985).

In this paper we examine the development of sheep and cattle embryos cultured in stoppered tubes under various gas atmospheres with a reduced oxygen concentration relative to air. 


\section{Materials and Methods}

Media and chemicals. The basic medium used for all embryoculture work was Synthetic Oviduct Fluid supplemented with $32 \mathrm{mg}$ crystallized and lyophilized bovine serum albumin/ml (Sigma, St Louis, MO, USA; SOF + BSA) as described by Tervit et al. (1972). The medium used for the recovery and handling of ova was an $N$-2-hydroxyethylpiperazine- $N^{\prime}-2-$ ethanesulphonic acid (Hepes; Sigma)-buffered SOF supplemented with $3 \mathrm{mg} \mathrm{BSA} / \mathrm{ml}$ (Hepes-SOF), in which the $\mathrm{NaHCO}_{3}$ concentration was reduced from 25 to $5 \mathrm{~mm}$ and replaced with $20 \mathrm{~mm}$-Hepes. Sodium pyruvate, sodium lactate and $\mathrm{CaCl}_{2}$ were from the Sigma Chemical Company. All other components were from BDH Chemicals (Poole, Dorset, UK).

Preparation of culture vessels. Gases containing oxygen concentrations of $0,2,4,6,8,10,12,17$ and $20 \%$ plus $5 \% \mathrm{CO}_{2}$ with the balance made up with $\mathrm{N}_{2}$ were supplied as individual cylinders of gas (NZIG, Wellington, New Zealand). To equilibrate the medium with the appropriate gas atmosphere, 1-ml samples of SOF + BSA in $5 \mathrm{ml}$ Pyrex test-tubes (BDL, Lincoln Park, NJ, USA) were vigorously gassed for $2 \mathrm{~min}$. Gases were passed through a $0.2 \mu \mathrm{m}$ filter (Millipore, Bedford, MA, USA) and a 20-gauge hypodermic needle positioned inside the test-tube but above the surface of the medium to prevent excessive bubbling. At the end of each gassing, the test-tube was tightly stoppered with a rubber bung. Tubes were then incubated overnight at $39^{\circ} \mathrm{C}$ before embryo culture. Once embryos were allocated to test-tubes for culture, each tube was regassed for $30 \mathrm{sec}$ with the appropriate gas mixture.

Collection and culture of sheep embryos. Embryos for culture were obtained from mature, mixed breed ewes superovulated and mated to entire rams. On Day 2-2.5 after detection of oestrus, ewes were slaughtered at an abattoir and the reproductive tracts were immediately flushed with warm Hepes-SOF. Ova were isolated from flushings and 2-cell embryos pooled and transported to the laboratory. On arrival, embryos were washed four times in Hepes-SOF, then once in SOF + BSA before random allocation to a gas atmosphere.

The 2-cell embryos ( $n=126,4$ replicates per treatment of 3-4 embryos per tube) were incubated for 5 days at $39^{\circ} \mathrm{C}$ under the 9 different oxygen concentrations. At the end of culture, embryos were recovered and general morphology was assessed under a dissecting microscope. Embryos were then stained with Hoechst 33342 (Pursel et al., 1985) or aceto-lacmoid to evaluate numbers of nuclei. The proportion of embryos that had reached at least the morula stage ( 24 nuclei or more) was examined by regression analysis after logit transformation.

Collection and culture of cow embryos. Embryos for culture were obtained from superovulated Friesian and Jersey cows artificially inseminated with frozen-thawed semen (Livestock Improvements Association, Newstead, New Zealand). On Day 2-3 after detection of oestrus the cows were slaughtered and embryos were collected and handled in the same manner as for sheep embryos, with the exception that 4- and early 8-cell embryos were obtained and utilized as well as 2-cell embryos.

The 2-4-cell embryos ( $n=61,3$ replicates per treatment of 3-4 embryos per tube) and early 8-cell embryos $(n=$ 99,3 replicates per treatment of 5-7 embryos per tube) were incubated for 5 days at $39^{\circ} \mathrm{C}$ under 6 different oxygen concentrations $(0,4,8,12,17$ and $20 \%)$. At the end of culture, embryos were evaluated as for sheep embryos. The proportions of 2-4-cell embryos that had reached at least the morula stage (24 nuclei or more) and of 8-cell embryos that were even more advanced ( 32 nuclei or more) were examined separately by regression analysis after logit transformation.

Determination of $\mathrm{O}_{2}$ concentration in media. To determine the effectiveness of the gassing regimen, an oxygen electrode (Diamond Electro-Tech, Ann Arbor, MI, USA) was used to evaluate oxygen concentration in culture media after gassing for $30 \mathrm{sec}$ or 2 min with 0 or $12 \% \mathrm{O}_{2}$ gas mixtures. A further experiment was conducted to determine whether oxygen levels in the medium changed after incubation for 5 days. Tubes were equilibrated with $0 \%(n=8)$ or $12 \%(n=7) \mathrm{O}_{2}$ for $2 \mathrm{~min}$, then tightly stoppered. Determination of $\mathrm{O}_{2}$ levels with an oxygen electrode was performed following incubation for 5 days at $39^{\circ} \mathrm{C}$.

\section{Results}

\section{Culture of sheep embryos}

Development of sheep embryos from the 2-cell stage to morula/blastocyst stages was observed after incubation under reduced oxygen concentrations in SOF (Fig. 1). Using logit-transformed proportions, regression analysis demonstrated a significant quadratic component for the different oxygen concentrations $\left(\chi_{1}^{2}=10.4, P<0.01\right.$, Fig. 1). Concentrations of $6-10 \%$ appeared to be superior for supporting embryo development to the morula stage. Poor development was observed at the $0 \%$ as well as the $20 \% \mathrm{O}_{2}$ concentration, indicating that oxygen is required for development, but at levels lower than that found in air. Mean ( $t$ s.e.m.) nuclei/embryo were $10 \cdot 8 \pm 1.9$, 
$20 \cdot 7 \pm 5 \cdot 2,23 \cdot 0 \pm 2 \cdot 7,19 \cdot 1 \pm 2 \cdot 2,23 \cdot 6 \pm 3 \cdot 1,19 \cdot 2 \pm 2 \cdot 2,17 \cdot 7 \pm 2 \cdot 0,19 \cdot 7 \pm 2 \cdot 1$ and $10 \cdot 3 \pm 0 \cdot 9$ for the 9 oxygen concentrations from 0 to $20 \%$ respectively.

The morphological appearance of embryos after in-vitro culture was usually poorer than for equivalent stages in vivo. Abnormalities observed included anucleate fragments, degenerate blastomeres, and many compact morulae with blastomeres outside the cell mass and lower than expected numbers of cells making up the mass.

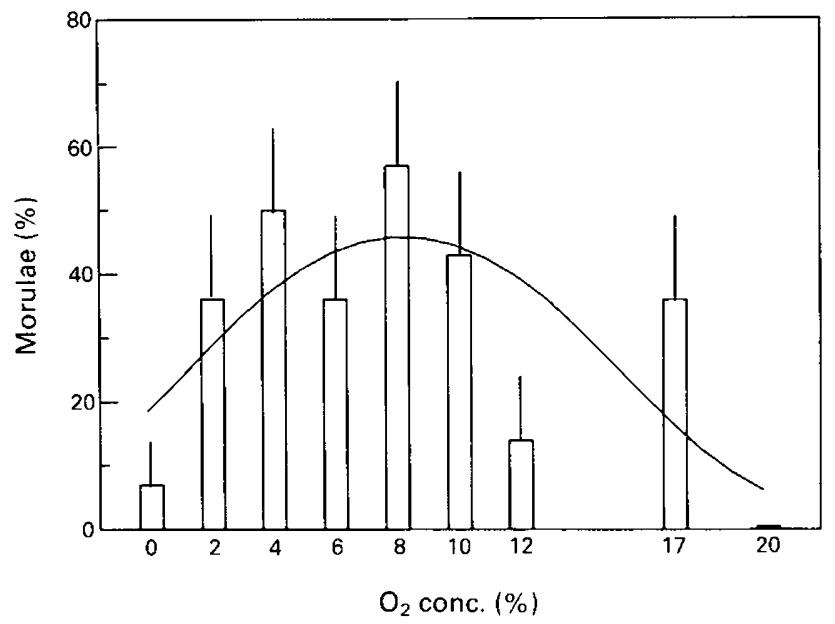

Fig. 1. Proportion of sheep 2-cell embryos developing to morulae ( $\geq 24$ nuclei) during culture for 5 days in SOF $+32 \mathrm{mg} \mathrm{BSA} / \mathrm{ml}$ under different oxygen concentrations. Bars represent standard errors. The line represents the back-transformed estimates from the quadratic regression.

\section{Culture of cattle embryos}

As with sheep embryos, development of 2-4-cell and early 8-cell cattle embryos to morula/ blastocyst stages occurred under reduced oxygen atmospheres (Fig. 2). Using logit-transformed proportions, regression analysis demonstrated no difference between the proportion of 2-4-cell embryos reaching the morula stage and 8-cell embryos reaching the compacting morula stage. As for sheep embryos, there was a significant quadratic component for the different oxygen concentrations $\left(\chi_{1}^{2}=4.3, P<0.05\right.$, Fig. 2). Concentrations of $4-12 \%$ oxygen in the atmosphere appeared best to support development to the morulae and compacting morulae stages. Oxygen levels of 0 and $20 \%$ did not readily support development. Mean ( \pm s.e.m.) nuclei/embryo were $16 \cdot 5 \pm 6 \cdot 0,23 \cdot 2 \pm 6 \cdot 1,16 \cdot 3 \pm 2 \cdot 9,15 \cdot 4 \pm 2 \cdot 2,13 \cdot 5 \pm 2 \cdot 4$ and $10 \cdot 3 \pm 2 \cdot 7$ for the 6 oxygen concentrations from 0 to $20 \%$ respectively for 2 -4-cell embryos and $14 \cdot 6 \pm 2 \cdot 4,20 \cdot 8 \pm 3 \cdot 3,29 \cdot 6 \pm 5 \cdot 2$, $21.9 \pm 3.9,20.2 \pm 2.5$ and $14.5 \pm 2.4$ for the 8-cell embryos. As with the sheep embryos, some embryos showed abnormalities.

\section{Oxygen equilibration after gassing}

Measured oxygen concentrations ( $\%$ mean \pm s.e.m., $n=10)$ after gassing for $30 \mathrm{sec}$ and 2 min were $5.1 \pm 0.8$ and $0.3 \pm 0.2$ with $0 \% \mathrm{O}_{2}$, and $15.1 \pm 0.2$ and $12.9 \pm 0.3$ with $12 \% \mathrm{O}_{2}$, respectively. The $\mathrm{pH}$ of the medium $(7 \cdot 3-7 \cdot 5)$ had equilibrated after gassing for 2 min. Furthermore, incubation for 5 days at $39^{\circ} \mathrm{C}$ did not affect oxygen tension. Measured oxygen levels for media gassed with $0 \% \mathrm{O}_{2}$ were approximately $0 \%$ in all cases and ranged from 11 to $12 \cdot 5 \%$ for media gassed with $12 \% \mathrm{O}_{2}$. 


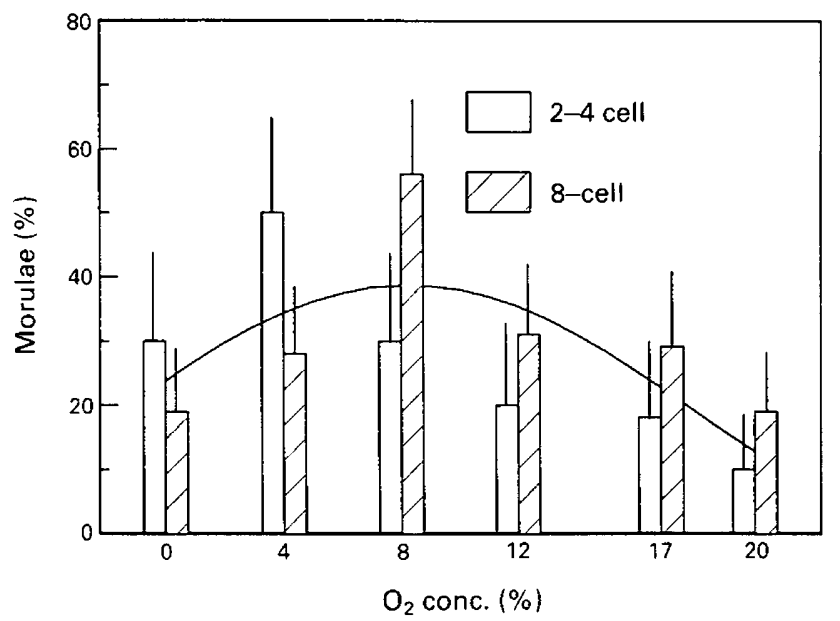

Fig. 2. Proportion of cow 2-4-cell embryos developing to morulae ( $\geq 24$ nuclei) and 8-cell embryos developing to compacting morulae ( $\geq 32$ nuclei) during culture for 5 days in SOF + $32 \mathrm{mg} \mathrm{BSA} / \mathrm{ml}$ under different oxygen concentrations. Bars represent standard errors. The line represents the back-transformed estimates from the overall quadratic regression.

\section{Discussion}

The results of our experiments demonstrate that, under the incubation conditions described here, oxygen concentration in the atmosphere is a factor involved in the development of sheep and cattle preimplantation embryos. Furthermore, our work supports the original observations of Tervit et al. (1972) that an oxygen concentration around 5-10\% is optimal for development of sheep and cattle embryos in vitro. Similar studies utilizing early mouse embryos demonstrated that $5 \% \mathrm{O}_{2}$ was optimal for development (Whitten, 1971; Quinn \& Harlow, 1978). However, other studies have not been able to demonstrate an effect of reduced oxygen concentration $(5 \%)$ on the development of sheep embryos (Wright et al., 1976; Betterbed \& Wright, 1985). Differences between media and incubating conditions (i.e. culturing in microdrops under oil) may explain the different findings between the present study and those of others.

To our knowledge, the $\mathrm{pO}_{2}$ tension in the sheep oviduct is not known. However, Mastroianni \& Jones (1965) reported that the $\mathrm{pO}_{2}$ tension in the rabbit oviduct is approximately $60 \mathrm{mmHg}(7 \cdot 8 \%)$, which falls within our suggested range of $6-10 \%$.

We have found that gassing for 2 min was adequate to equilibrate oxygen levels (and $\mathrm{pH}$ ) in the media. However, it is unlikely that true anaerobic conditions were created by gassing with $0 \% \mathrm{O}_{2}$ for this period of time. This may explain why development did occur in some replicates of this treatment.

The mechanism by which oxygen concentration in the atmosphere affects development in vitro remains to be elucidated. There is some evidence that developmental blocks during in-vitro culture are associated with metabolic processes. In hamsters, Schini \& Bavister (1988) have demonstrated that the 2-cell block to development can be overcome if glucose and inorganic phosphate ions are deleted from the medium. Increased development of 8-cell embryos to blastocyst stages is also achieved in the absence of glucose and inorganic phosphate (Seshagiri \& Bavister, 1989a, b). These authors suggest that inadequate energy generation is the cause of retarded development and is due to the Crabtree effect, whereby phosphate ions stimulate glycolysis and thus compete with mitochondrial respiration. There is also evidence that oxygen concentration may affect energy substrate $_{7 \mathrm{PM}}$ 
utilization in embryos. Khurana \& Wales (1989) have demonstrated that a reduced oxygen atmosphere $(1-5 \%)$ is necessary to promote the utilization of endogenous glycogen pools in cultured mouse morulae.

Auto-oxidation by oxygen-free radicals and lipid radicals is a major cause of cell damage and retarded cell growth during culture (Joenje, 1989). Lipid radicals can alter metabolic pathways, inhibiting proliferation of cells in culture (Hornsby \& Gill, 1981). Lowering the oxygen concentration, or providing protection by the addition of antioxidants, reduces this effect (Hornsby \& Gill, 1981; Hornsby, 1982). We suspect that a similar process occurs in cultured embryos. Incubating under reduced oxygen concentrations may reduce the auto-oxidative damage and provide adequate energy production to support development. Sheep and cattle embryos may be particularly susceptible to oxidative damage at the 8-cell stage, when transcription of the embryonic genome is activated (Crosby et al., 1988).

Attention is drawn to the observation that, although development was improved under physiological oxygen concentrations, embryos cultured in SOF $+32 \mathrm{mg} \mathrm{BSA} / \mathrm{ml}$ appeared to show more abnormalities than did embryos of equivalent stage recovered after development in vivo. Improved culture conditions, such as incubating in multiwell dishes (Thompson et al., 1989), alterations to the chemical composition of the medium, or the addition of human serum as described by Walker et al. (1988), growth factors or possibly other mitogenic factors associated with oviduct epithelial co-cultures (Gandolfi \& Moor, 1988), may improve the morphological appearance, and probably the viability, of cultured sheep and cattle ova.

We thank J. Peterson, L. McGowan, R. McLaughlin and J. Lange for technical assistance and D. Duganzich for statistical analyses.

\section{References}

Betterbed, B. \& Wright, R.W., Jr (1985) Development of one-cell ovine embryos in two culture media under two gas atmospheres. Theriogenology 23, 547-553.

Crosby, I.M., Gandolfi, F. \& Moor, R.M. (1988) Control of protein synthesis during cleavage of sheep embryos. J. Reprod. Fert. 82, 769-775.

Eyestone, W.H. \& First, N.L. (1989) Co-culture of early cattle embryos to the blastocyst stage with oviducal tissue or in conditioned media. J. Reprod. Fert. 85, $715-720$.

Gandolfi, F. \& Moor, R.M. (1987) Stimulation of early embryonic development in sheep by co-culture with oviduct epithelial cells. J. Reprod. Fert. 81, 23-28.

Gandolfi, F. \& Moor, R.M. (1988) Interactions between somatic and germinal cells during early development. Proc. Ilth Int. Congr. Anim. Reprod. \& A.I., Dublin, vol. 5, pp. 169-176.

Hornsby, P.J. (1982) The role of Vitamin E in cellular energy metabolism in cultured adrenocortical cells. $J$. cell. Physiol. 112, 207-216.

Hornsby, P.J. \& Gill, G.N. (1981) Regulation of glutamine and pyruvate oxidation in cultured adrenocortical cells by cortisol, antioxidants, and oxygen: Effects on cell proliferation. J. cell. Physiol. 109, 111-120.

Joenje, H. (1989) Genetic toxicology of oxygen. Mut. Res. 219, 193-208.

Khurana, N.K. \& Wales, R.G. (1989) Effects of oxygen concentration on the metabolism of $\left[\mathrm{U}-{ }^{14} \mathrm{C}\right] \mathrm{glucose}$ by mouse morulae and early blastocysts. Reprod. Fertil. Devel. 1, 99-106.
Mastroianni L., Jr \& Jones, R. (1965) Oxygen concentration within the rabbit Fallopian tube. J. Reprod. Fert. 9, 99-102.

Pursel, V.G., Wall, R.J., Rexroad, C.E., Jr, Hammer, R.E. \& Brinster, R.L. (1985) A rapid whole-mount staining procedure for nuclei of mammalian embryos. Theriogenology 24, 687-691.

Quinn, P. \& Harlow, G.M. (1978) The effect of oxygen on the development of preimplantation mouse embryos in vitro. J. exp. Zool. 206, 73-80.

Quinn, P., Warnes, G.M., Walker, S.K. \& Seamark, R.F. (1984) Culture of preimplantation sheep and goat embryos. In Reproduction in Sheep, pp. 289-290. Eds D. R. Lindsay \& D. T. Pearce. Australian Academy of Science and Australian Wool Corporation, Canberra.

Rexroad, C.E., Jr \& Powell, A.M. (1988) Co-culture of ovine ova with oviductal cells in medium 199. $J$. Anim. Sci 66, 947-953.

Schini, S.A. \& Bavister, B.D. (1988) Two-cell block to development of cultured hamster embryos is caused by phosphate and glucose. Biol. Reprod. 39, 1183-1192.

Seshagiri, P.B. \& Bavister, B.D. (1989a) Glucose inhibits development of hamster 8-cell embryos in vitro. Biol. Reprod. 40, 599--606.

Seshagiri, P.B. \& Bavister, B.D. (1989b) Phosphate is required for the inhibition by glucose of development of hamster 8-cell embryos in vitro. Biol. Reprod. $\mathbf{4 0}$, 607-614.

Tervit, H.R. Whittingham, D.G. \& Rowson, L.E.A. (1972) Successful culture in vitro of sheep and cattle ova. J Reprod. Fert. 30, $493-497$. 
Tervit, H.R. \& Rowson, L.E.A. (1974) Birth of lambs after culture of sheep ova in vitro for up to 6 days. $J$. Reprod. Fert. 38, 177-179.

Thompson, J.G.E., Parton, G.A.J., Cruickshank, G.W., Smith, J.F. \& Wales, R.G. (1989) Development of sheep preimplantation embryos in media supplemented with glucose and acetate. Theriogenology 32, 323-330.

Walker, S.K., Seamark, R.F., Quinn, P., Warnes, G.M., Ashman, R.J., Smith, D.K. \& Ancell, P. (1988) Culture of pronuclear embryos of sheep in a simple medium. Proc. Ilth Int. Congr. Anim. Reprod. \& A.I. Dublin, vol. 4, p. 483.
Whitten, W.K. (1971) Nutrient requirements for the culture of preimplantation embryos in vitro. Adv. Biosc. 6, 129-141.

Wright, R.W., Jr \& Bondioli, K.R. (1981) Aspects of in vitro fertilization and embryo culture in domestic animals. J. Anim. Sci. 53, 702-729.

Wright, R.W., Jr, Anderson, G.B., Cupps, P.T., Drost, M. \& Bradford, G.E. (1976) In vitro culture of embryos from adult and prepuberal ewes. J. Anim. Sci. 42, 912-917.

Received 18 October 1989 